\title{
Knockdown of hypoxia inducible factor-2 $\alpha$ inhibits cell invasion via the downregulation of MMP-2 expression in breast cancer cells
}

\author{
$\mathrm{NA} \mathrm{LI}^{1 *}, \mathrm{HONGXING} \mathrm{WANG}^{2 *}, \mathrm{JIE} \mathrm{ZHANG}^{1}$ and ERCHEN ZHAO ${ }^{1}$ \\ Departments of ${ }^{1}$ Pathology and ${ }^{2}$ Clinical Immunology, Xinxiang Medical University, Xinxiang, Henan 453003, P.R. China
}

Received January 17, 2015; Accepted March 15, 2016

DOI: $10.3892 / 01.2016 .4471$

\begin{abstract}
Hypoxia inducible factors (HIFs) are important regulatory molecules of the intracellular oxygen-signaling pathway. The role of HIF-1 $\alpha$ has been confirmed in breast carcinoma; however, little is understood concerning the function of HIF- $2 \alpha$. The present study treated human breast adenocarcinoma MCF-7 cells with the HIF activator cobalt chloride, and transfected HIF-2 $\alpha$ small interfering RNAs (siRNAs) into MCF-7 cells to suppress HIF-2 $\alpha$ expression. The siRNAs significantly reduced the levels of HIF-2 $\alpha$ and matrix metalloproteinase (MMP)-2 in the treated MCF-7 cells. An invasion assay demonstrated that the siRNAs targeting HIF- $2 \alpha$ inhibited the invasion potency of the cells. The present study concludes that loss of HIF- $2 \alpha$ may be associated with a decreased risk for the progression of human breast cancer, due to the downregulation of the expression of MMP-2.
\end{abstract}

\section{Introduction}

Hypoxia inducible factors (HIFs) belong to the family of helix-loop-helix-PAS domain transcription factors $(1,2)$. It has been demonstrated that there are $\sim 150$ HIF target genes (3). HIFs accelerate tumor progression and cell survival by regulating a wide variety genes that control various metabolic processes, including anaerobic metabolism (glucose transporter 1), angiogenesis (vascular endothelial growth factor), regulation of cell cycle and intracellular $\mathrm{pH}$ (carbonic anhydrase-9), response to DNA damage, alteration of the extracellular matrix and cell adhesion, migration, proliferation and apoptosis [p21, p27, matrix metalloproteinase (MMP)-2 and 9] (4-7). The HIF pathway in hypoxia is an important therapeutic target for reducing the size, metastatic potential and therapeutic resistance of the primary tumor (8).

Correspondence to: Dr Na Li, Department of Pathology, Xinxiang Medical University, 601 Jinsui Road, Xinxiang, Henan 453003, P.R. China

E-mail: yaoyao-lina@163.com

${ }^{*}$ Contributed equally

Key words: HIF-2 $\alpha$, MMP-2, siRNA, breast cancer, invasion
There are three isoforms of the HIF- $\alpha$ subunit: HIF-1 $\alpha$, HIF- $2 \alpha$ and HIF-3 $\alpha$. HIF-2 is dimerized by the HIF- $1 \beta$ subunit and HIF- $2 \alpha$ subunit, and the stability and transcriptional activity of HIF- $2 \alpha$ is accommodated by oxygen-dependent hydroxylation. In normoxic conditions, the $\alpha$ subunit is constitutively expressed but rapidly degraded. In a low-oxygen environment, the $\alpha$ subunit is stabilized and translocated to the nucleus $(9,10)$. HIF-2 $\alpha$ is regulated by fewer genes compared with HIF-1 $\alpha$; in breast adenocarcinoma MCF-7 cells, there are only a small group of hypoxia-associated genes that are associated with HIF-2 $\alpha$, while $80 \%$ of hypoxia-regulated genes are associated with HIF-1 $\alpha$, including vascular endothelial growth factor, erythropoietin and matrix metalloproteinases $(11,12)$. Previous studies have confirmed that HIF-1 is associated with tumor progression in certain carcinomas, including breast, non-small cell lung and uterine cancer, and patients with high levels of HIF-1 have a poor response to cancer therapies (13-19). However, little is understood concerning the effect of HIF-2 $\alpha$ in solid tumors. Previous studies have demonstrated that a cell's reaction to hypoxia is primarily regulated by HIF-1 $\alpha$ in all cells, including breast carcinoma cells, but is regulated by HIF-2 $\alpha$ in gastrointestinal epithelium, heart, kidney, and renal carcinoma cells (20).

RNA interference (RNAi) is a powerful mechanism for targeting post-transcriptional gene silencing, in which double-stranded RNA is successfully introduced into mammalian cells, which downregulates the expression of target genes or suppresses the replication and transcription of pathogens by degrading the homologous mRNA sequences (21). In the present study, synthesized small interfering (si) RNAs targeting the HIF-2 $\alpha$ gene was transfected into breast adenocarcinoma MCF-7 cells using Lipofectamine ${ }^{\circledR} 2000$ to knockdown the expression of the HIF- $2 \alpha$ on a protein and mRNA level. Results from studies regarding the effect and impact of HIF- $2 \alpha$ gene silencing on the cell growth and invasion potency may contribute to additional research on the HIF complex and its possible therapeutic applications. The present study investigated the correlation between HIF-2 $\alpha$ and MMP-2 expression, and the significant role of HIF- $2 \alpha$ in breast carcinoma cell survival and invasion.

\section{Materials and methods}

Cell lines and hypoxia treatment. The breast adenocarcinoma MCF-7 cell line was purchased from the Shanghai Institute of 
Biochemistry and Cell Biology (Shanghai, China). The cells were cultured in RPMI-1640 medium (Invitrogen; Thermo Fisher Scientific, Inc., Waltham, MA, USA) supplemented with $10 \%$ fetal calf serum (Invitrogen; Thermo Fisher Scientific, Inc.), streptomycin (100 U/ml; Thermo Fisher Scientific, Inc.) and penicillin (100 U/ml; Thermo Fisher Scientific, Inc.) at $37^{\circ} \mathrm{C}$ in $5 \% \mathrm{CO}_{2}$. When the cells had reached $80 \%$ confluence, they were cultured with hypoxia-mimetic agent, cobalt chloride $\left(\mathrm{CoCl}_{2} ;\right.$ Sigma-Aldrich, St. Louis, MO, USA) at various concentrations $(50,100$ and $200 \mu \mathrm{mol} / \mathrm{l})$ for at $37^{\circ} \mathrm{C}$ in $5 \% \mathrm{CO}_{2}$ for $24 \mathrm{~h}$. A maximum HIF-2 $\alpha$ accumulation was reached at $100 \mu \mathrm{mol} / 1 \mathrm{CoCl}_{2}$; therefore, $100 \mu \mathrm{mol} / 1 \mathrm{CoCl}_{2}$ was selected for use as the standard concentration for subsequent experiments (Fig. 1).

siRNAs and transfection. The HIF-2 $\alpha$ siRNAs were designed according to the study by Meade et al (22) and were synthesized by Guangzhou Ruibo Biological Technology Co., Ltd. (Guangzhou, China) as follows: siRNA-1, sense 5'-GCAAAU GUACCCAAUGAUADTDT-3' and antisense 5'-UAUCAU UGGGUACAUUUGCDTDT-3'; siRNA-2, sense 5'-CAGCAU CUUUGAUAGCAGUDTDT-3' and antisense 5'-ACUGCU AUCAAAGAUGCUGDTDT-3'; negative control siRNA, sense 5'-CAGCAGGGUUGAUAGCAUGDTDT-3' and antisense 5'-ACUGCCCCCAAAGAUGCUGDTDT-3æ. The MCF-7 cells were transfected with the siRNAs. Briefly, the cells were seeded into 24 -well plates and cultured in RPMI-1640 medium for $24 \mathrm{~h}$ (at $37^{\circ} \mathrm{C}$ in $5 \% \mathrm{CO}_{2}$ ) to reach $50-70 \%$ confluence. HIF- $2 \alpha$ siRNA or the negative control siRNA were transfected into the cells using Lipofectamine ${ }^{\circledR} 2000$ (Invitrogen; Thermo Fisher Scientific, Inc.). The cells were placed in a normoxic or hypoxic atmosphere for $24 \mathrm{~h}$ following transfection. The experimental groups were as follows: Parental cell group, MCF-7 cells without $\mathrm{CoCl}_{2}$ treatment; control group, MCF-7 cells treated with $100 \mu \mathrm{mol} / \mathrm{l}$ $\mathrm{CoCl}_{2}$; hypoxia + RNAi 1 group, HIF-2 $\alpha$ siRNA1-transfected MCF-7 cells treated with $100 \mu \mathrm{mol} / 1 \mathrm{CoCl}_{2}$; hypoxia + RNAi 2 group, HIF-2 $\alpha$ siRNA2-transfected MCF-7 cells treated with $100 \mu \mathrm{mol} / 1 \mathrm{CoCl}_{2}$.

Reverse transcription polymerase chain reaction (PCR). Total RNA was extracted from the cells using TRIzol reagent (Gibco ${ }^{\circledR}$; Thermo Fisher Scientific, Inc.). The cDNA was synthesized from the RNA using the Reverse Transcription System (Promega Corporation, Madison, WI, USA), according to the manufacturer's protocol. The expressions of HIF- $2 \alpha$ and MMP-2 were detected using the following primers: HIF-2 $\alpha$, forward 5'-TGAAAACAGAGTCCGAAGCC-3' and reverse 5'-GTGGCTGACTTGAGGTTGA-3'; MMP-2, forward 5'-TTCAAGGACCGGTTCATTTGGCGGACT GTG-3' and reverse 5'-TTCCAAACTTCACGCTCTTCAGAC TTTGGTT-3'. The following glyceraldehyde-3-phosphate dehydrogenase (GAPDH) primers were also used: forward, 5'-ATTCATCTCTCCTCTCCCA-3' and reverse, 5'-GTTGGTGGTTGGTACTGT-3'. Primers were designed using the Primer Premier Software version 5 (Premier Biosoft International, Palo Alto, CA, USA) and synthesized by Invitrogen (Thermo Fisher Scientific, Inc.). PCR was performed using the SYBR Premix Ex Taq II kit (Takara Biotechnology Co., Ltd., Dalian, China) and the ABI 9700 PCR system (Applied
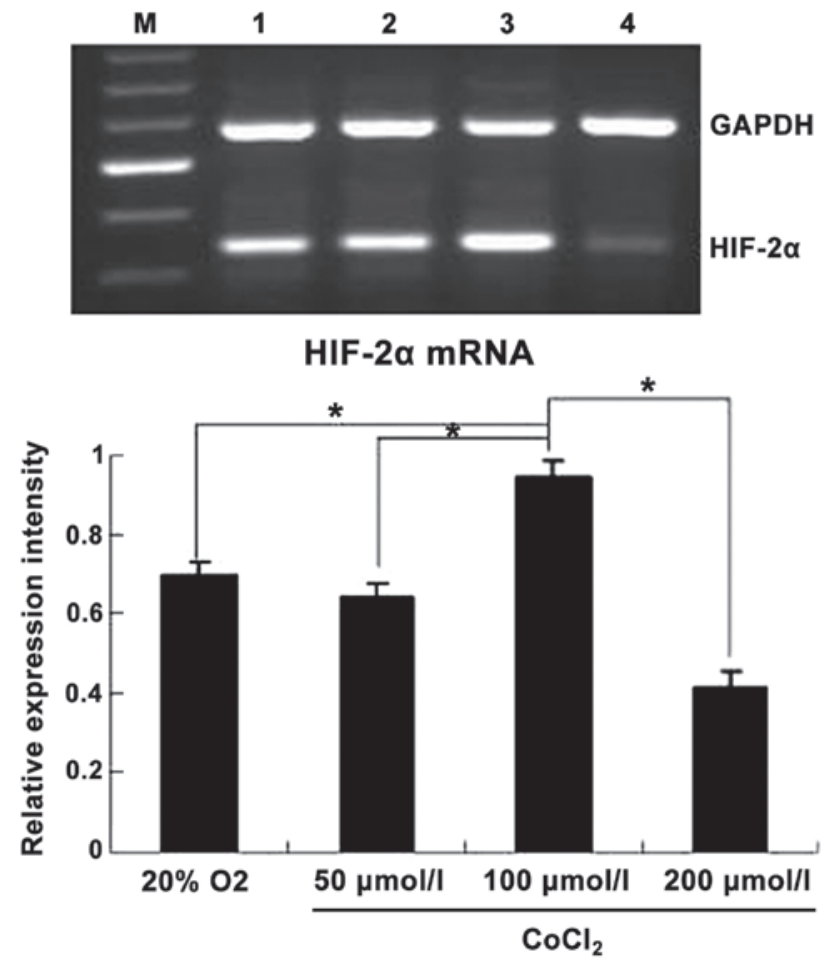

Figure 1. HIF-2 $\alpha$ mRNA expression in human breast carcinoma MCF-7 cells Lane 1, cells cultured under normoxic conditions $\left(20 \% \mathrm{O}_{2}\right)$; lane 2, cells treated with $50 \mu \mathrm{mol} / 1 \mathrm{CoCl}_{2}$; lane 3 , cells treated with $100 \mu \mathrm{mol} / 1 \mathrm{CoCl}_{2}$; lane 4 , cells treated with $200 \mu \mathrm{mol} / 1 \mathrm{CoCl}_{2}$. The data are represented as the mean \pm standard deviation. ${ }^{*} \mathrm{P}<0.05$ vs. normoxic conditions. HIF- $2 \alpha$, hypoxia-inducible factor- $2 \alpha$; $\mathrm{CoCl}_{2}$, cobalt chloride; GAPDH, glyceraldehyde 3 -phosphate dehydrogenase.

Biosystems; Thermo Fisher Scientific, Inc.), and under the following conditions: $94^{\circ} \mathrm{C}$ for $45 \mathrm{sec}$ and $55^{\circ} \mathrm{C}$ for $1 \mathrm{~min}$ for 35 cycles, with an initial denaturation step at $72^{\circ} \mathrm{C}$ for $10 \mathrm{~min}$. The PCR products were subjected to $1.5 \%$ agarose gel electrophoresis, with GAPDH (580 bp) as an internal control. PCR products were quantified with a TotalLab Quant Phoretix 1D Pro software software (TotalLab Ltd., Newcastle Upon Tyne, UK).

Western blotting analysis. Protein was extracted from the cells using NP-40 Lysis Buffer (Beyotime Institute of Biotechnology, Haimen, China). Protein concentration was determined using a bicinchoninic acid assay (Beyotime Institute of Biotechnology), according to the manufacturer's protocol. Total protein of breast carcinoma cells was separated by $10 \%$ sodium dodecyl sulfate-polyacrylamide gel electrophoresis. Proteins were displaced to polyvinylidene difluoride (PVDF) membranes by Pharmacia Phast gel electrophoresis system (Roche Diagnostics, Indianapolis, IN, USA). The PVDF membrane was blocked with 5\% skim milk blocking buffer (Beyotime Institute of Biotechnology) for $1 \mathrm{~h}$. The immunoblots were incubated with the following primary antibodies: Rabbit polyclonal anti-HIF-2 $\alpha$ (dilution, 1:150; catalog no., ab73895; Abcam, Cambridge, UK); mouse monoclonal anti-MMP-2 (dilution, 1:500; catalog no., ab3158; Abcam); and mouse monoclonal anti- $\beta$-actin (dilution, 1:500; catalog no., ab6276; Abcam). Subsequently, the membranes were incubated at $4^{\circ} \mathrm{C}$ for $24 \mathrm{~h}$ with gentle agitation. After washing twice with 

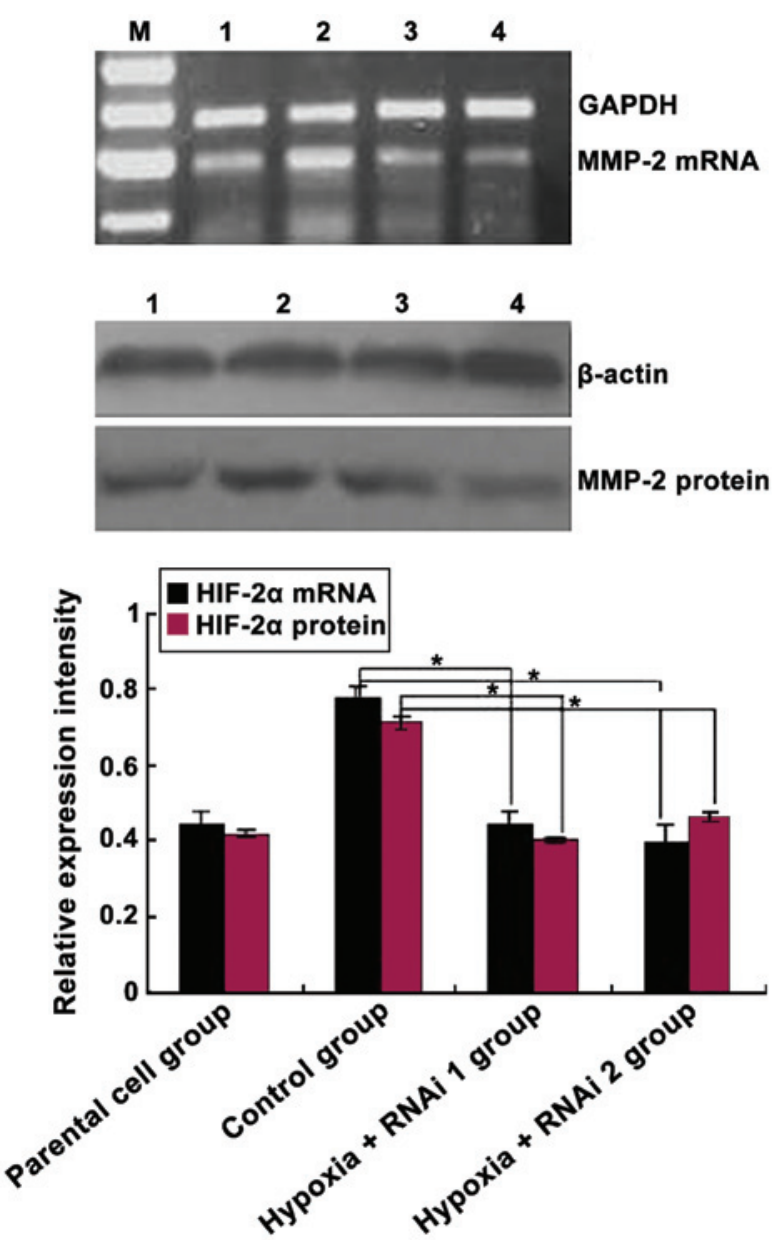

Figure 2. Effects of HIF-2 $\alpha$ knockdown on the expression of HIF-2 $\alpha$ protein and mRNA in breast adenocarcinoma MCF-7 cells. Lane 1, cells cultured under normoxic conditions $\left(20 \% \mathrm{O}_{2}\right)$; lane 2, cells treated with $50 \mu \mathrm{mol} / \mathrm{l}$ $\mathrm{CoCl}_{2}$; lane 3, cells treated with $100 \mu \mathrm{mol} / 1 \mathrm{CoCl}_{2}$; lane 4, cells treated with $200 \mu \mathrm{mol} / 1 \mathrm{CoCl}_{2}$. The data are represented as the mean \pm standard deviation. ${ }^{2} \mathrm{P}<0.05$ vs. parental cell group. HIF- $2 \alpha$, hypoxia-inducible factor- $2 \alpha$; siRNA, small interfering RNA; RNAi, RNA interference; GAPDH, glyceraldehyde 3-phosphate dehydrogenase.

phosphate-buffered saline, the membranes were incubated with horseradish peroxidase-conjugated goat anti-rabbit (dilution, 1:1,000; catalog no., BA1054-1; BosterBio, Wuhan, China) and goat anti-mouse (dilution, 1:1,000; catalog no., BA1051; BosterBio) IgG secondary antibodies for $1 \mathrm{~h}$ at room temperature. After washing with PBS, the immuno-blotting signal was detected using a chemiluminescence system (ECL; Thermo Fisher Scientific, Inc.). The results were quantified using TotalLab version 2.0 software (Total Lab, Newcastle upon Tyne, UK). $\beta$-actin protein was used as an internal control.

Invasion assays. The invasion ability of the cells was detected using a Boyden chamber (BD Biosciences, Franklin Lakes, NJ, USA. For invasion assays, polycarbonate filters with 8- $\mu \mathrm{m}$ pore size (EMD Millipore, Billerica, MA, USA) were covered with Matrigel (Sigma-Aldrich), which was diluted to 1:20 with serum-free RPMI-1640 medium (Invitrogen; Thermo Fisher Scientific, Inc.). The polycarbonate filters were dried at room temperature for $24 \mathrm{~h}$. In total, $\sim 5 \times 10^{6}$ cells in $500 \mu \mathrm{l}$ RPMI-1640 media were placed in the upper chamber and $400 \mu 1$ RPMI-1640 medium was placed in the lower chamber.
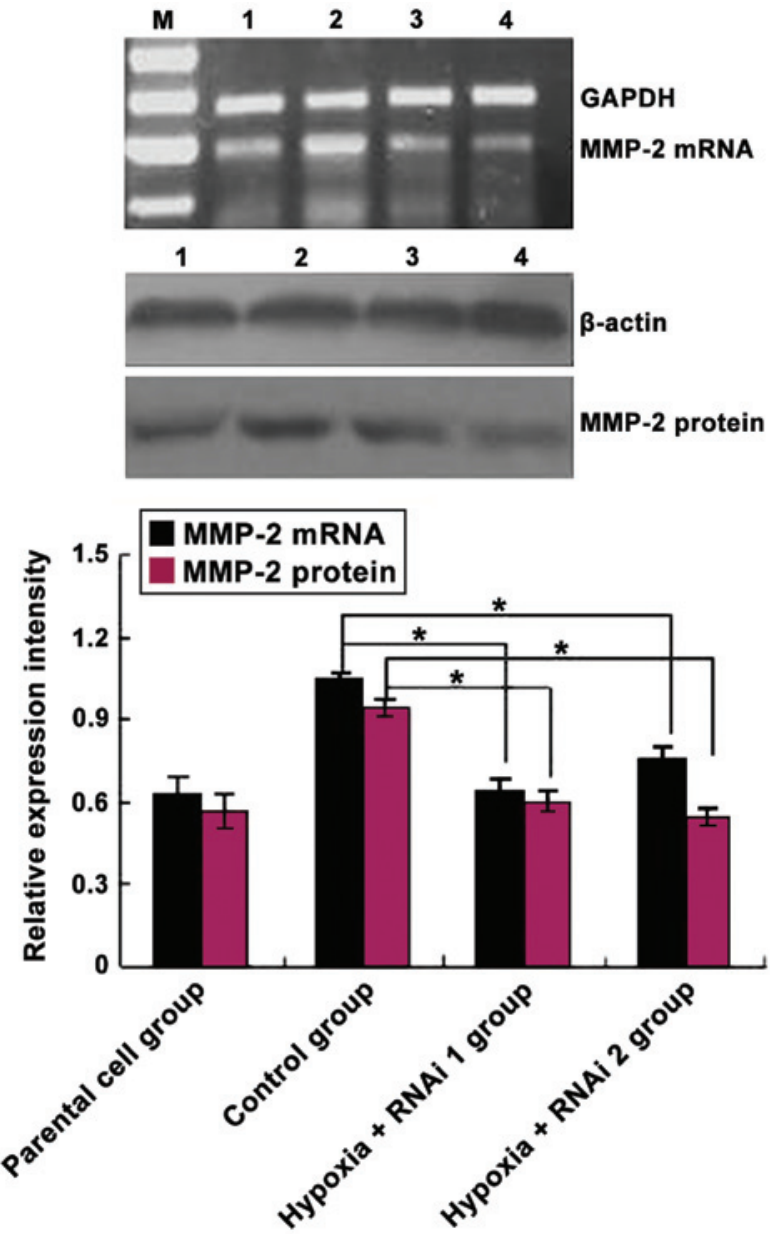

Figure 3. Effects of HIF-2 $\alpha$ knockdown on the expression of target gene MMP-2 protein and mRNA in breast adenocarcinoma MCF-7 cells. Lane 1, cells cultured under normoxic conditions $\left(20 \% \mathrm{O}_{2}\right)$; lane 2 , cells treated with $50 \mu \mathrm{mol} / 1 \mathrm{CoCl}_{2}$; lane 3, cells treated with $100 \mu \mathrm{mol} / 1 \mathrm{CoCl}_{2}$; lane 4 , cells treated with $200 \mu \mathrm{mol} / 1 \mathrm{CoCl}_{2}$. The data are represented as the mean \pm standard deviation. ${ }^{*} \mathrm{P}<0.05$ vs. parental cell group. HIF- $2 \alpha$, hypoxia-inducible factor-2 $\alpha$; MMP, matrix metalloproteinase; siRNA, small interfering RNA; RNAi, RNA interference; GAPDH, glyceraldehyde 3-phosphate dehydrogenase.

The cells were incubated at $37^{\circ} \mathrm{C}$ in $5 \% \mathrm{CO}_{2}$ for $24 \mathrm{~h}$. The cells on the bottom surface of the polycarbonate filter were removed and fixed in $4 \%$ glutaraldehyde solution and stained with hematoxylin and eosin (Enzyme-linked Biotechnology Co., Ltd., Shanghai, China). Invasive cells were counted using a microscope (magnification, x400; BX51; Olympus Corp., Tokyo, Japan). The invasion index and the cell invasion inhibition rate were calculated as previously described (23). Briefly, the invasion index was defined as the number of cells that migrated through the $8-\mu \mathrm{m}$ pores of the filter in the experimental group divided by the number of cells that migrated through the filter in the control group $\mathrm{x}$ 100. The cell invasion inhibition rate was equal to the number of cells that migrated through the filter in the control group minus the number of cells that migrated through the filter in the experimental group divided by the number of cells that migrated through the filter in the control group x 100.

Statistical analysis. The data are presented as the mean \pm standard deviation. Experiments were performed in triplicate. All 
Table I. Effects of HIF-2 $\alpha$ small interfering RNA on the invasion potency of human breast adenocarcinoma MCF-7 cells.

\begin{tabular}{|c|c|c|c|}
\hline Group & No. of cells & Invasion index, $\%$ & Cell invasion inhibition rate, $\%$ \\
\hline Parental cell & $16.63 \pm 11.84^{\mathrm{a}}$ & $59.06^{\mathrm{a}}$ & $40.94^{\mathrm{a}}$ \\
\hline Control & $28.16 \pm 10.16$ & 100.00 & - \\
\hline Hypoxia + RNAi 1 & $14.44 \pm 11.12^{\mathrm{a}}$ & $51.28^{\mathrm{a}}$ & $48.72^{\mathrm{a}}$ \\
\hline Hypoxia + RNAi 2 & $13.86 \pm 15.12^{\mathrm{a}}$ & $49.22^{\mathrm{a}}$ & $50.78^{\mathrm{a}}$ \\
\hline
\end{tabular}

The data are presented as the mean \pm standard deviation. ${ }^{\mathrm{a}} \mathrm{P}<0.05$ vs. control group. HIF- $2 \alpha$, hypoxia inducible factor- $2 \alpha$; siRNA, small interfering RNA; RNAi, RNA interference.

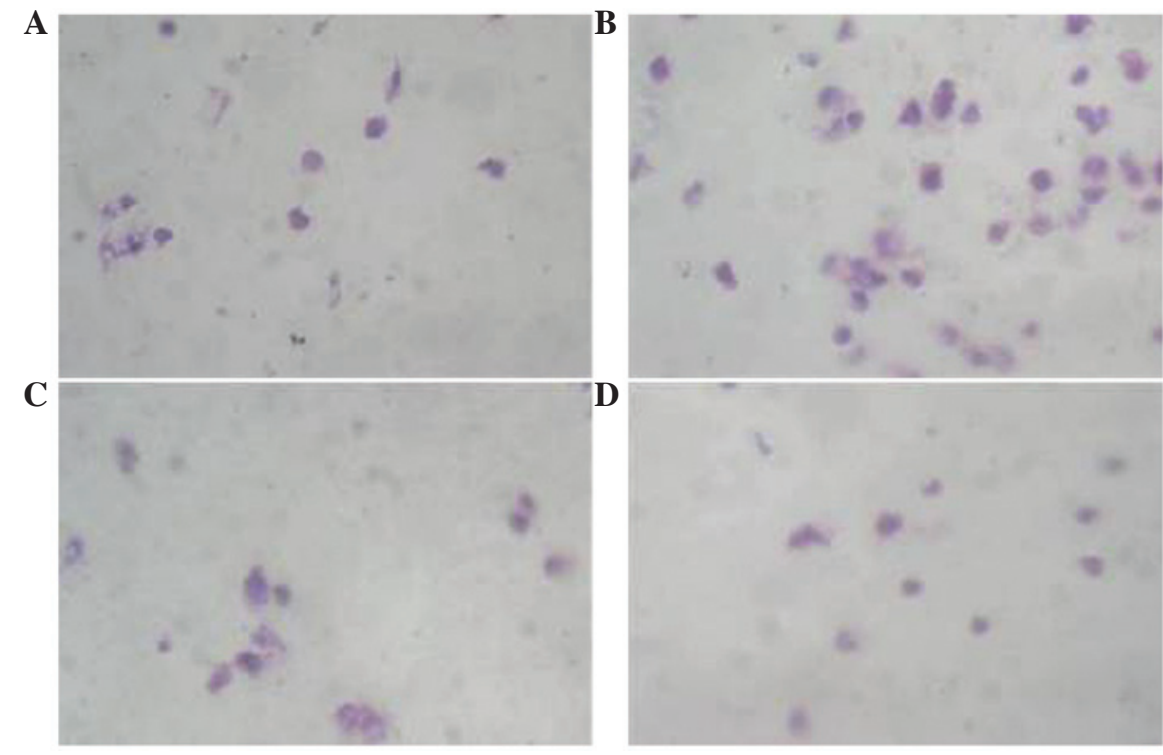

Figure 4. Suppression effects of hypoxia-inducible factor- $2 \alpha$ small interfering RNA on the invasion potency of breast adenocarcinoma MCF-7 cells. Migrated cells were stained with hematoxylin and eosin from the (A) parental cell, (B) control, (C) hypoxia + RNAi 1 and (D) hypoxia + RNAi 2 groups. A significant reduction in the number of invaded cells indicated a decrease in the invasive potency of the treated cells. RNAi, RNA interference.

statistical analyses were performed using SPSS version 13.0 software (SPSS, Inc., Chicago, IL, USA). Independent sample t-test was used to determine the statistical significance between the means. $\mathrm{P}<0.05$ was considered to indicate a statistically significant difference.

\section{Results}

Hypoxia mimetic $\mathrm{CoCl}_{2}$ specifically elevated HIF-2 $\alpha \mathrm{mRNA}$ levels. To investigate whether the expression of HIF-2 $\alpha$ is regulated by a hypoxic environment, the mRNA levels of HIF- $2 \alpha$ were compared in cells that were cultured under normoxic $\left(20 \% \mathrm{O}_{2}\right)$ and hypoxia-mimetic $\left(\mathrm{CoCl}_{2}\right)$ conditions. After a $24 \mathrm{~h}$ incubation, HIF- $2 \alpha \mathrm{mRNA}$ levels clearly increased in the cells that were treated with $\mathrm{CoCl}_{2}(100 \mu \mathrm{mol} / \mathrm{l})$. It has been established that $\mathrm{CoCl}_{2}$ treatment can prevent oxygen signaling in cells, leading to chemical hypoxia. The results revealed that the hypoxic effect increased in severity as $\mathrm{CoCl}_{2}$ dose increased from 50 to $100 \mu \mathrm{mol} / 1$. This indicates that $\mathrm{CoCl}_{2}$ induces hypoxia in a dose-dependent manner. In addition, the expression of HIF-2 $\alpha$ also increased in a dose-dependent manner. Notably, the toxicity of $\mathrm{CoCl}_{2}$ increased in a dose-dependent manner and thus at high doses this led to severe hypoxia and subsequent cell death. As a result, the expression of HIF- $2 \alpha$ was decreased. By contrast, normoxic conditions $\left(20 \% \mathrm{O}_{2}\right)$ had only a slight effect on HIF-2 $\alpha$ transcription (Fig. 1). De novo transcription of GAPDH was similar among treatment groups. These results suggest that exposure of $\mathrm{CoCl}_{2}(100 \mu \mathrm{mol} / \mathrm{l})$ promoted HIF- $2 \alpha$ transcription, evidenced by the increase in HIF- $2 \alpha$ mRNA levels. A $\mathrm{CoCl}_{2}$ concentration of $100 \mu \mathrm{mol} / 1$ was used in all subsequent experiments.

Effects of HIF-2 $\alpha$ knockdown on the expression of MMP-2 in MCF-7 cells. The association between HIF-2 $\alpha$ expression and its target gene MMP-2 was analyzed in MCF-7 cells using siRNAs against HIF- $2 \alpha$. As expected, HIF-2 $\alpha$ siRNA markedly reduced the mRNA and protein levels of the targeted HIF-2 $\alpha$ subunit (Fig. 2). Subsequently, the effects of HIF-2 $\alpha$ knockdown on $\mathrm{CoCl}_{2}$-mediated induction of MMP-2 expression was analyzed. As shown in Fig. 3, MMP-2 protein and mRNA levels were downregulated significantly in MCF-7 cells transfected with HIF- $2 \alpha$ siRNA compared with the control group $(\mathrm{P}=0.033)$. Overall, these data demonstrated that hypoxia induces HIF-2 $\alpha$ expression at mRNA and protein levels in MCF-7 cells, and HIF-2 $\alpha$ siRNA inhibited MMP-2 expression in MCF-7 cells. 
Effects of HIF-2 $\alpha$ siRNAs on cancer cell invasion. The effects of HIF- $2 \alpha$ siRNAs on cell migration were assessed using a Boyden chamber assay, which has been modified. As shown in Fig. 4, HIF-2 $\alpha$ siRNA significantly inhibited cell migration compared with the control group (hypoxia + RNAi 1, $\mathrm{P}<0.006$; hypoxia + RNAi 2, $\mathrm{P}=0.004)$. By contrast, the migratory ability of the control group cells were significantly increased compared with the hypoxia + RNAi groups (hypoxia + RNAi 1, P<0.006; hypoxia + RNAi 2, P=0.004) (Fig. 4). There was no difference on the migratory capabilities of the hypoxia + RNAi groups compared with the parental cell group $(\mathrm{P}=0.176)$. These data suggest that $\mathrm{HIF}-2 \alpha$ was a positive regulator for cell invasion and HIF- $2 \alpha$ siRNA may inhibit the invasive capacity of MCF-7 cells (Table I).

\section{Discussion}

Hypoxia is common in numerous types of solid tumors, where tumor cells proliferate rapidly and form large solid tumor masses, leading to obstruction and compression of the blood vessels surrounding these masses. These abnormal blood vessels often do not function properly, resulting in a poor $\mathrm{O}_{2}$ supply to the center tumor regions. Tumor cells in this hypoxic region begin to adapt these low oxygen tension conditions by activating several survival pathways, including the HIF pathway $(22,24,25)$. The responses of cells to hypoxia are mediated primarily through HIFs, which are critical mediators in the cellular and systemic hypoxia response to low oxygen levels via the accommodation of numerous genes that are induced by hypoxia (14,26-28). The activation of the HIF transcription factor is the most commonly identified pathway activated by hypoxic cells in harsh microenvironments. Activated HIFs exhibit a crucial role in adaptive responses of tumor cells to changes in $\mathrm{O}_{2}$ levels via transcriptional activation of $>100$ downstream genes which regulate vital biological processes required for tumor survival and progression. Examples include genes involved in glucose metabolism, cell proliferation, migration and angiogenesis (29). Currently, the role of HIF-2 $\alpha$ in certain solid tumors is unclear.

The present study investigated the association and significance between the expression of HIF- $2 \alpha$ and clinical features of breast carcinoma tissue. The author's previous histological studies have demonstrated that a higher expression of the HIF-2 $\alpha$ protein is associated with breast cancer invasion and metastasis (30). The aim of the present study was to reveal whether HIF-2 $\alpha$ has effects on the invasion potency of human breast carcinoma MCF-7 cells, and to reveal a possible mechanism for this function under hypoxia by using the RNAi method.

$\mathrm{CoCl}_{2}$ prevents HIF-1 $\alpha$ from binding to prolyl hydroxylases, so that they are not hydroxylated and are subsequently degraded by proteasomes (31). $\mathrm{CoCl}_{2}$ has been used in in vivo and in vitro studies to generate hypoxia by inhibiting HIF-1 specific prolyl-hydroxylase and occupying its iron-binding site, leading to impaired binding of the von Hippel-Lindau protein with HIF-1 $\alpha$, subsequently preventing HIF-1 $\alpha$ proteasomal degradation (32). Since $\mathrm{CoCl}_{2}$ stabilizes the $\alpha$ subunits of HIFs, the transcription of HIF-targeted genes may be induced by HIFs in spite of the presence of oxygen $(4,33)$.
$\mathrm{CoCl}_{2}$ has been successfully used to mimic hypoxia in in vivo and in vitro experimental studies (34). In the present study, a hypoxia model was successfully established through $\mathrm{CoCl}_{2}$ treatment of MCF-7 cells. The present results demonstrated that $\mathrm{CoCl}_{2}$ treatment induces HIF-2 $\alpha$ transcription and translation and increases the mRNA and protein expressions of HIF- $2 \alpha$. Additionally, transfection with HIF-2 $\alpha$ siRNA inhibited the expression of HIF- $2 \alpha$ mRNA and protein, which indicated that the silencing effect of siRNA on HIF- $2 \alpha$ was successful. Furthermore, the present experiments revealed that HIF- $2 \alpha$ siRNA inhibited breast cancer cell invasion abilities; basement membrane assays reveled that there were a decreased number of invading HIF- $2 \alpha$ siRNA transfected MCF-7 cells under hypoxic conditions in vitro compared with control cells. This finding suggests that HIF- $2 \alpha$ may be important in MCF-7 cell survival and invasion. These results are similar to a previous study that revealed that HIF- $2 \alpha$ promotes tumor progression in Von-Hippel-Lindau-defective renal carcinoma cells (12). By contrast in other tumor types, HIF-2 $\alpha$ has an important role as a tumor suppressor; embryonic stem cells are deficient in HIF-2 $\alpha$ and display enhanced growth in ovarian tumors (35). In addition, a high-expression of HIF-2 $\alpha$ may suppress tumor growth in brain glioma cells (36).

In the present study, in order to verify whether HIF-2 $\alpha$ affects MMP-2 expression, siRNA against HIF-2 $\alpha$ was used to downregulate the expression of HIF- $2 \alpha$ in MCF-7 cells. The results indicated that the expression of MMP-2 mRNA and protein decreased once MCF-7 cells were transfected with HIF- $2 \alpha$ siRNA under hypoxic conditions. Collectively, the present findings demonstrate that the regulation of MMP-2 by hypoxia leads to increased invasion of breast cancer cells, which facilitates metastasis.

In conclusion, the present study has demonstrated for the first time, to the best of our knowledge, that HIF-2 $\alpha$ is endogenously expressed in eukaryotic cells. In a hypoxia-tolerant tumor cell line (MCF-7) HIF-2 $\alpha$ is involved in tumor cell invasion in vitro, which confirms the present author's hypothesis: HIF-2 $\alpha$ facilitates cancer cell metastasis in hypoxic environments. Collectively, the present results provide a novel mechanism that HIF-2 $\alpha$ signaling is important for cancer development and cancer cell survival by altering the expression of the downstream targets, including MMP-2. Notably, the present study revealed that siRNA targeting of HIF- $2 \alpha$ may be a viable approach in the treatment of malignant diseases.

\section{Acknowledgements}

The present study was supported by the University Key Teacher Grant from the Ministry of Education of Henan (Zhengzhou, China; grant no. 2012GGJS-136) and Scientific Research Fund of Xinxiang Medical University (Xinxiang, China; grant no. 2014QN113).

\section{References}

1. Bohensky J, Terkhorn SP, Freeman TA, Adams CS, Garcia JA, Shapiro IM and Srinivas V: Regulation of autophagy in human and murine cartilage: Hypoxia-inducible factor 2 suppresses chondrocyte autophagy. Arthritis Rheum 60: 1406-1415, 2009. 
2. Mole DR, Blancher C, Copley RR, Pollard PJ, Gleadle JM, Ragoussis J and Ratcliffe PJ: Genome-wide association of hypoxia-inducible factor (HIF)- $1 \alpha$ and HIF- $2 \alpha$ DNA binding with expression profiling of hypoxia-inducible transcripts. J Biol Chem 284: 16767-16775, 2009.

3. Kütscher C, Lampert FM, Kunze M, Markfeld-Erol F, Stark GB and Finkenzeller G: Overexpression of hypoxia-inducible factor-1 alpha improves vasculogenesis-related functions of endothelial progenitor cells. Microvasc Res 105: 85-92, 2016.

4. Rankin EB, Rha J, Unger TL, Wu CH, Shutt HP, Johnson RS, Simon MC, Keith B and Haase VH: Hypoxia-inducible factor-2 regulates vascular tumorigenesis in mice. Oncogene 27: 5354-5358, 2008.

5. Copple BL, Bai S and Moon JO: Hypoxia-inducible factor-dependent production of profibrotic mediators by hypoxic Kupffer cells. Hepatol Res 40: 530-539, 2010.

6. Wykoff CC, Sotiriou C, Cockman ME, Ratcliffe PJ, Maxwell P, Liu E and Harris AL: Gene array of VHL mutation and hypoxia shows novel hypoxia-induced genes and that cyclin D1 is a VHL target gene. Br J Cancer 90: 1235-1243, 2004.

7. Liu W, Xin H, Eckert DT, Brown JA and Gnarra JR: Hypoxia and cell cycle regulation of the von Hippel-Lindau tumor suppressor. Oncogene 30: 21-31, 2011.

8. Zhao S, Jin C, Zhao X, Jin B, Hui L, Zhou W, Niu G and Tao S: Expression and clinical significance of ING4 and HIF-1 alpha in brain astrocytoma. Zhonghua Yi Xue Za Zhi 95: 3533-3536, 2015 (In Chinese).

9. Burrows N, Babur M, Resch J, Williams KJ and Brabant G: Hypoxia-inducible factor in thyroid carcinoma. J Thyroid Res 2011: 762905, 2011

10. Trisciuoglio D, Gabellini C, Desideri M, Ziparo E, Zupi G and Del Bufalo D: Bcl-2 regulates HIF-1 $\alpha$ protein stabilization in hypoxic melanoma cells via the molecular chaperone HSP90. PLoS One 5: e11772, 2010.

11. Mardilovich K and and Shaw LM: Hypoxia regulates insulin receptor substrate-2 expression to promote breast carcinoma cell survival and invasion. Cancer Res 69: 8894-8901, 2009. 10.1158/0008-5472.CAN-09-1152.

12. Raval RR, Lau KW, Tran MGB, Sowter HM, Mandriota SJ, Li JL, Pugh CW, Maxwell PH, Harris AL and Ratcliffe PJ: Contrasting properties of hypoxia-inducible factor 1 (HIF-1) and HIF-2 in von Hippel-Lindau-associated renal cell carcinoma. Mol Cell Biol 25: 5675-5686, 2005.

13. Mazumdar J,Hickey MM,Pant DK, Durham AC,Sweet-Cordero A, Vachani A, Jacks T, Chodosh LA, Kissil JL, Simon MC and Keith B: HIF-2 $\alpha$ deletion promotes Kras-driven lung tumor development. Proc Natl Acad Sci USA 107: 14182-14187, 2010.

14. Florczyk U, Czauderna S, Stachurska A, Tertil M, Nowak W, Kozakowska M, Poellinger L, Jozkowicz A, Loboda A and Dulak J: Opposite effects of HIF-1 $\alpha$ and HIF- $2 \alpha$ on the regulation of IL-8 expression in endothelial cells. Free Radic Biol Med 1: 1882-1892, 2011.

15. Rankin EB, Rha J, Selak MA, Unger TL, Keith B, Liu Q and Haase VH: Hypoxia-inducible factor 2 regulates hepatic lipid metabolism. Mol Cell Biol 29: 4527-4538, 2009.

16. Choi YK, Kim CK, Lee H, Jeoung D, Ha KS, Kwon YG, Kim KW and Kim YM: Carbon monoxide promotes VEGF expression by increasing HIF-1 $\alpha$ protein level via two distinct mechanisms, translational activation and stabilization of HIF-1 $\alpha$ protein. J Biol Chem 285: 32116-32125, 2010.

17. Kapitsinou PP, Liu Q, Unger TL, Rha J, Davidoff O, Keith B, Epstein JA, Moores SL, Erickson-Miller CL and Haase VH Hepatic HIF-2 regulates erythropoietic responses to hypoxia in renal anemia. Blood 116: 3039-3048, 2010.

18. Rankin EB, Biju MP, Liu Q, Unger TL, Rha J, Johnson RS Simon MC, Keith B and Haase VH: Hypoxia-inducible factor-2 (HIF-2) regulates hepatic ery thropoietin in vivo. J Clin Invest 117: 1068-1077, 2007.
19. Wei K, Piecewicz SM, McGinnis LM, Taniguchi CM, Wiegand SJ, Anderson K, Chan CW, Mulligan KX, Kuo D, Yuan J, et al: A liver Hif- $2 \alpha$-Irs2 pathway sensitizes hepatic insulin signaling and is modulated by Vegf inhibition. Nat Med 19: 1331-1337, 2013.

20. Qiu Y, Zheng H, Sun LH, Peng K, Xiao WD and Yang H: Hypoxia-inducible factor-1 modulates upregulation of mutT homolog-1 in colorectal cancer. World J Gastroenterol 21: 13447-13456, 2015.

21. Fukasawa T, Enomoto A and Miyagawa K: Serine-Threonine Kinase 38 regulates CDC25A stability and the DNA damage-induced G2/M checkpoint. Cell Signal 27: 1569-1575, 2015.

22. Meade ES, Ma YY and Guller S: Role of hypoxia-inducible transcription factors $1 \alpha$ and $2 \alpha$ in the regulation of plasminogen activator inhibitor-1 expression in a human trophoblast cell line. Placenta 28: 1012-1019, 2007

23. Li N, Wang HX, Zhang A, Ye YP and He GY: KISS-1 inhibits the proliferation and invasion of gastric carcinoma cells. World J Gastroenterol 18: 1827-1833, 2012.

24. Semenza GL: Defining the role of hypoxia-inducible factor 1 in cancer biology and therapeutics. Oncogene 29: 625-634, 2010.

25. Bensellam M, Duvillié B, Rybachuk G, Laybutt DR, Magnan C, Guiot Y, Pouysségur J and Jonas JC: Glucose-induced $\mathrm{O}_{2}$ consumption activates hypoxia inducible factors 1 and 2 in rat insulin-secreting pancreatic beta-cells. PLoS One 7: e29807, 2012.

26. Jing SW, Wang YD, Kuroda M, Su JW, Sun GG, Liu Q, Cheng YJ and Yang CR: HIF-1 $\alpha$ contributes to hypoxia-induced invasion and metastasis of esophageal carcinoma via inhibiting E-cadherin and promoting MMP-2 expression. Acta Med Okayama 66: 399-407, 2012.

27. Leonard MO, Howell K, Madden SF, Costello CM, Higgins DG, Taylor CT and McLoughlin P: Hypoxia selectively activates the CREB family of transcription factors in the in vivo lung. Am J Respir Crit Care Med 178: 977-983, 2008.

28. Gordan JD, Bertout JA, Hu CJ, Diehl JA and Simon MC: HIF-2 $\alpha$ promotes hypoxic cell proliferation by enhancing c-myc transcriptional activity. Cancer Cell 11: 335-347, 2007.

29. Huang KT, Takano EA, Mikeska T, Byrne DJ, Dobrovic A and Fox SB: Aberrant DNA methylation but not mutation of CITED4 is associated with alteration of HIF-regulated genes in breast cancer. Breast Cancer Res Treat 130: 319-329, 2011.

30. Li N, Wang HX, Qin C, Wang XH and Han FY: Relationship between clinicopathological features and HIF-2 $\alpha$ in gastric adenocarcinoma. Genet Mol Res 14:1404-1413, 2015.

31. Xiao H, Gu Z, Wang G and Zhao T: The possible mechanisms underlying the impairment of HIF-1 $\alpha$ pathway signaling in hyperglycemia and the beneficial effects of certain therapies. Int J Med Sci 10: 1412-1421, 2013.

32. Yokoe S, Nakagawa T, Kojima Y, Higuchi K and Asahi M: Indomethacin-induced intestinal epithelial cell damage is mediated by pVHL activation through the degradation of collagen I and HIF-1 $\alpha$. Biochem Biophys Res Commun 468: 671-676, 2015.

33. Zhu P, Ning Y, Yao L, Chen $\mathrm{M}$ and $\mathrm{Xu} \mathrm{C}$ : The proliferation, apoptosis, invasion of endothelial-like epithelial ovarian cancer cells induced by hypoxia. J Exp Clin Cancer Res 29: 124, 2010.

34. Yoo HI, Moon YH and Kim MS: Effects of $\mathrm{CoCl} 2$ on multi-lineage differentiation of C3H/10T1/2 mesenchymal stem cells. Korean J Physiol Pharmacol 20:53-62, 2016.

35. Wang Q, Peng K and He L: Expression of the HIF-2 $\alpha$ in epithelial ovarian cancer and clinical significance. Zhong Nan Da Xue Xue Bao Yi Xue Ban 39:889-893, 2014.

36. Anelli V, Gault CR, Cheng AB and Obeid LM: Sphingosine kinase 1 is up-regulated during hypoxia in U87MG glioma cells. Role of hypoxia-inducible factors 1 and 2. J Biol Chem 283: 3365-3375, 2008 